\title{
A Model-Based Meta-Analysis of Willingness to Participate in Cancer Screening
}

\author{
Guangchao Charles Feng ${ }^{1, *}$, Zhiliang Lin ${ }^{2}$, Wanhua Ou ${ }^{1}$, Xianglin $\mathrm{Su}^{1}$ and Qing Yan ${ }^{3}$ \\ 1 College of Communication, Shenzhen University, Shenzhen 518600, China; \\ winnie.ouwh@hotmail.com (W.O.); 2170094510@email.szu.edu.cn (X.S.) \\ 2 School of Literature and Media, Nanfang College of Sun Yat-sen University, Guangzhou 510970, China; \\ linzhl@nfu.edu.cn \\ 3 School of Journalism and Communication, Jinan University, Guangzhou 510610, China; tyq2008@jnu.edu.cn \\ * Correspondence: fffchao@gmail.com
}

\section{check for}

updates

Citation: Feng, G.C.; Lin, Z.; Ou, W.; $\mathrm{Su}, \mathrm{X}$; Yan, Q. A Model-Based Meta-Analysis of Willingness to Participate in Cancer Screening. Int. J Environ. Res. Public Health 2021, 18, 2580. https://doi.org/10.3390/ ijerph18052580

Received: 2 February 2021

Accepted: 27 February 2021

Published: 4 March 2021

Publisher's Note: MDPI stays neutral with regard to jurisdictional claims in published maps and institutional affiliations.

Copyright: (c) 2021 by the authors. Licensee MDPI, Basel, Switzerland. This article is an open access article distributed under the terms and conditions of the Creative Commons Attribution (CC BY) license (https:// creativecommons.org/licenses/by/ $4.0 /)$.

\begin{abstract}
Although early screening tests are beneficial for the detection and treatment of cancers, many people have failed to participate in screening tests. The present study aims to explore the theoretical underpinning of low participation in screening programs using the method of metaanalytic structural equation modeling. It was found that the health belief model is the most adopted theoretical framework. Moreover, the intended uptake of screening was positively predicted only by cues to action, health literacy, and perceived susceptibility. As a result, a health intention model, including the three significant variables, is proposed. The practical implications of the findings are that health communication campaigns should focus on enlightening and engaging the public through all necessary means to raise awareness and transfer knowledge in relation to screening procedures as well as cancers per se.
\end{abstract}

Keywords: cancer screening; model-based meta-analysis; health belief model

\section{Introduction}

Cancer is one of the leading causes of morbidity and mortality worldwide [1] (the primary studies included in the present meta-analysis are marked with asterisks in the References section). However, a substantial proportion of cancer-related deaths could be prevented [2] if the early detection of cancer, such as through medically warranted cancer screening, could be undertaken [3]. Cancer screening in the present study is defined as detecting cancer at an asymptomatic stage of development using medical screening services $[3,4]$. Consequently, some means of prevention, such as self-examination of breast and using self-purchased medical kits, are irrelevant. A high number of screening trials have shown the efficacy of cancer screening in reducing cancer-specific mortality for cancers of the breast, colon, mouth, skin, rectum, larynx, cervix, and lung $[2,3,5,6]$. Consequently, measures of early cancer detection, such as mammography associated with breast cancer, colonoscopy, sigmoidoscopy, high-sensitivity fecal occult blood tests (FOBTs) associated with colorectal cancer, low-dose helical computed tomography associated with lung cancer, and Pap test and human papillomavirus (HPV) testing associated with cervical cancer, are strongly recommended (for the recommendations of the United States Preventative Services Task Force (USPSTF) regarding cancer-screening practices, see USPSTF [7-11]).

Despite the fact that early screening tests are beneficial for the detection and treatment of cancers, many people in the recommended age groups $[7,12,13]$ have failed to participate in screening tests $[4,14]$. Low participation in screening programs has been attributed to patient, health professional, and organizational factors [3], specifically including the lack of knowledge [15,16] and physician recommendations [17], health insurance status [18], socioeconomic inequalities [17,19], and a variety of barriers $[20,21]$. These are all important 
factors, but a premium has to be placed on the elucidation of theoretical models of preventive health behavior [22]. As some [23,24] have pointed out, it is urgent to develop and adopt theory-based intervention programs to increase healthy behaviors. Valid theories can not only consistently explain why a phenomenon persists to develop effective interventions but also predict what will happen in the future to take preventive measures (see [25]). Studies that address cancer screening behavioral intentions are abundant but often lack enough integration of the relevant theories. According to our discursive search in major databases, at least 14 theories have been applied in this area (for a review, see [3]). Among them, the health belief model (HBM) [26,27], whose extensions account for $40 \%$ of the studies in our sample, is the most popular, followed by the theory of reasoned action (TRA) [28,29] and its extension, namely, the theory of planned behavior (TPB) [30]. Due to its popularity, the HBM will be primarily employed in the following analyses, whereas its connections with other closely related models are duly addressed.

The research purpose of the present study is twofold. One is to estimate the common effect sizes explaining cancer-screening intention and behaviors, and the other one is to find and examine a conceptual model that can adequately account for cancer-screening intention and behaviors. The first purpose is usually achieved by conventional univariate meta-analysis, whereas we will conduct an innovative model-based meta-analysis using the technique called meta-analytic structural equation modeling (MASEM) to achieve the two objectives sequentially.

\section{Literature Review}

\subsection{Health Belief Model (HBM) and Its Extensions}

The HBM [31] was originally formulated in response to the failure of a free tuberculosis (TB) health-screening program and was later developed to account for a variety of both long- and short-term preventive health behaviors. The HBM $[26,27,32,33]$ hypothesizes that a person will take a health-related action if the individual perceives a severe negative health outcome (perceived severity), feels susceptible to it (perceived susceptibility), perceives high benefits of undertaking the preventive behavior (perceived benefits), or perceives low barriers to adopting those behaviors. In addition, the model also includes a cue to action whereby the individual is driven to engage in preventive behavior. Cues to action could include external cues, such as a public service announcement or interpersonal interaction, or internal cues such as the perception of an unsound bodily state [26,32,33].

Some researchers [34-36] modified the HBM while hypothesizing that screening intentions are directly influenced by the factor of perceived benefits, which are directly influenced by the susceptibility to the health threat and the perceived severity of the threat, and the costs of the action. The HBM later included the component of self-efficacy [37] as well as the incentive to behave (health motivation) [38].

\subsection{Theory of Reasoned Action (TRA) and Theory of Planned Behavior (TPB)}

The health belief model (HBM) essentially explains the relationships between both internal and external health beliefs and health behaviors (or intentions), whereas such generalized connections are well documented in the TRA and its extension, namely, the TPB. The TRA has also been adopted to study various types of cancer screening behavioral intentions [39-41], and some expanded TRA has been employed for the same purpose. For instance, Montano and associates [39,42] incorporated affect, habit, and facilitating conditions into their expanded TRA to predict mammography participation.

Many also have applied the TPB to examine participation in cancer screening [43-46]. Despite its popularity, Gaston and Gerjo [47] reported that the TPB could explain $41 \%$ of the variance in intention but only $34 \%$ of the variance in a variety of health behaviors. Therefore, some have made extensions to the TPB by including more factors to better account for actual behavior. For instance, Conner and Armitage [48] extended the TPB by including past behavior and habit, belief salience, affect, self-identity, and moral norms, among others (also see [49]). The information-motivation-behavioral skill model (IMB) [50] expanded the 
TPB by adding the component of functional cancer literacy, which includes three domains: breast cancer awareness, knowledge and screening, and prevention and control.

\subsection{Research Questions}

Dissimilar theories with numerous predictors or similar theories with diverse combinations and configurations of predictors have been adopted to the same end, i.e., to account for the determinants of preventive health behavior. Some predictors were found to be important in some studies, but contrary conclusions were found in other studies. Consequently, a meta-analysis, which is a means of quantitatively estimating the overall effect based on previous research findings on a particular topic [51-53], is intended to clarify this confusion. Due to its popularity, several univariate meta-analyses have been used with the health belief model (HBM) [54-57] or the HBM equivalent [58]. The meta-analysis of Carpenter [55] also found that barriers and benefits were strong predictors, but severity and susceptibility were not. In their meta-analysis, Harrison, Mullen and Green [54] concluded that the factor of costs (barriers) is a relatively more critical predictor, whereas the effect of severity is negligible, and benefits and susceptibility play a minor role in contributing to screening behavior. In the meta-analysis of the protection motivation theory (PMT), which is a variant of the HBM, Milne, Sheeran and Orbell [58] found that the association between threat appraisal (severity, vulnerability, and fear) and intention was small, whereas the associations between the coping-appraisal variables (self-efficacy, and costs or barriers) and intention were moderate. Moreover, all of these predictors had weaker associations with behaviors than with intentions. Therefore, the inconsistency in the findings remains among these meta-analyses.

The correlations and complex relationships (e.g., moderation and mediation) in any theoretical models will affect the magnitude and the standard error of the statistic for testing the relationship between the predictor of interest and the dependent variable. Therefore, univariate meta-analysis as reviewed above inevitably shares the deficiency of primary studies, i.e., failing to shed light on the true relationships among the variables of a theory. In fact, few primary studies merely examined the bivariate correlation in actual studies but rather addressed more complex theoretical relationships through incorporating either covariates, moderators, or mediators [59]. Model-based as opposed to separate univariate correlation-based meta-analysis is a technique that can be used to analyze complex chains of events [60] and hence is adopted in the present study. Furthermore, due to the correspondence among the aforementioned value-expectancy-based theories, a meta-analysis focusing on any one of them would just prioritize idiosyncrasies but would be subject to the loss of generality. Accordingly, the present study elects to seek all of the pieces of the theoretical framework by studying the common outcome using the modelbased meta-analysis, i.e., the behavior and intentions of participating in cancer screening, and subsequently form a variety of combinations of the pieces; that is, the main purpose of the meta-analysis study is not to confirm the hypotheses stipulated in the relevant theories or models, so we will raise the following research questions rather than hypotheses:

1. What are the magnitudes of effects of perceived severity, perceived barriers, perceived benefits, health literacy, cues to action, perceived susceptibility, and perceived behavioral control on cancer-screening intentions and behaviors?

2. What kinds of significant relationships among the predictors mentioned in the first research question and outcomes (cancer-screening intentions and behaviors) are present? Which theories underpin these relationships?

\section{Methods}

\subsection{Classification of Constructs}

Based on the "core health cognitions" framework of McMillan and Conner [61], we identified the major constructs associated with the abovementioned theories and then consolidated these constructs into nine core categories: cues to action, health literacy, norms, perceived behavioral control, risk perceptions (including perceived severity and 
susceptibility), perceived barriers, intentions, and screening behavior. We inspected the variables' underlying meanings in the included studies and allocated the variables to the nine construct categories on a "close fit" basis [24].

\subsection{Selection Criteria}

Since cancer-screening intentions and behaviors are the focus of our study, we tried combinations of the following keywords, namely, "screening tests for *ancer", "cancer* screening", "screening for * cancer", "intent ${ }^{*}$ cancer", "participate* cancer", "compl* cancer", and "adher* cancer", in eight different databases, including EMBASE, Cochrane Database of Systematic Reviews, PsycINFO, PubMed, Web of Science, Scopus, and Google Scholar, for published articles related to various factors associated with participation in cancer screening. The searching and selecting process followed the PRISMA (Preferred Reporting Items for Systematic Reviews and Meta-Analyses) recommendations (see Figure 1), and the three research assistants of the first author finished the process. The first round of the search started in November 2019, yielding 12,427 potentially eligible studies. We then made a screening of these articles. The selection criteria for the studies to be included in this meta-analysis were as follows: (a) quantitative studies with effect sizes; (b) articles with theoretical variables concerning the determinants and adherence or intentions of cancer screening (studies using only medical variables were hence excluded); and (c) reporting complete zero-order correlations among independent variables and dependent variables. After a series of filtered searches, we obtained 56 eligible articles.

For those articles not satisfying criterion c, we contacted the corresponding authors to request the missing information. This step retrieved an additional 10 eligible studies. We additionally searched through the reference lists of all located studies and obtained eight eligible articles. The final count of the total number of relevant eligible articles reached 70 with 3288 valid effect sizes (cumulative $n=754,294$ ).

\subsection{Unit of Analysis}

The unit of analysis is the effect size, which is the correlations (Pearson's or other types of correlations that are appropriate for other measurement levels) between the intention to participate in cancer screening and a few predictors. The experts of MASEM [59,62] do not recommend the method of Fisher's $\mathrm{z}$ transformation and back-transformation in MASEM. Consequently, in the following analyses, the original correlation will not be transformed into Fisher's z, a popular procedure termed the Rosenthal [53] approach by Johnson et al. [63], in order to retain the correlation metric and the associated variances and covariances among the correlations for use in Stage 2 of MASEM.

\subsection{Coding Categories of the Moderators}

Differences in the methods and sample characteristics may introduce variability ("heterogeneity") among the true effects. Therefore, once heterogeneity is detected, the moderator analysis is imperative. The following information was coded from each article: (a) date of publication (range $=(1990,2017), 84.507 \%$ of studies were conducted after 2000); (b) number of observations ( $\mathrm{M}=1256, \mathrm{SD}=4624)$; (c) journal names; (d) data types (crosssectional (85.915\%) vs. time series); (e) sampling types (random or probability sampling $(66.197 \%)$ vs. convenience sampling); (f) country of study (countries were classified into individualistic (81.690\%) vs. collectivistic categories according to Hofstede [64]); and (g) cancer types (breast cancer, colorectal cancer, cervical cancer, both breast and cervical cancer, and a general type without specifying the name accounted for 24 (33.803\%), 19 $(26.760 \%), 8(11.268 \%), 19(26.760 \%)$, and $1(1.408 \%)$, respectively). 


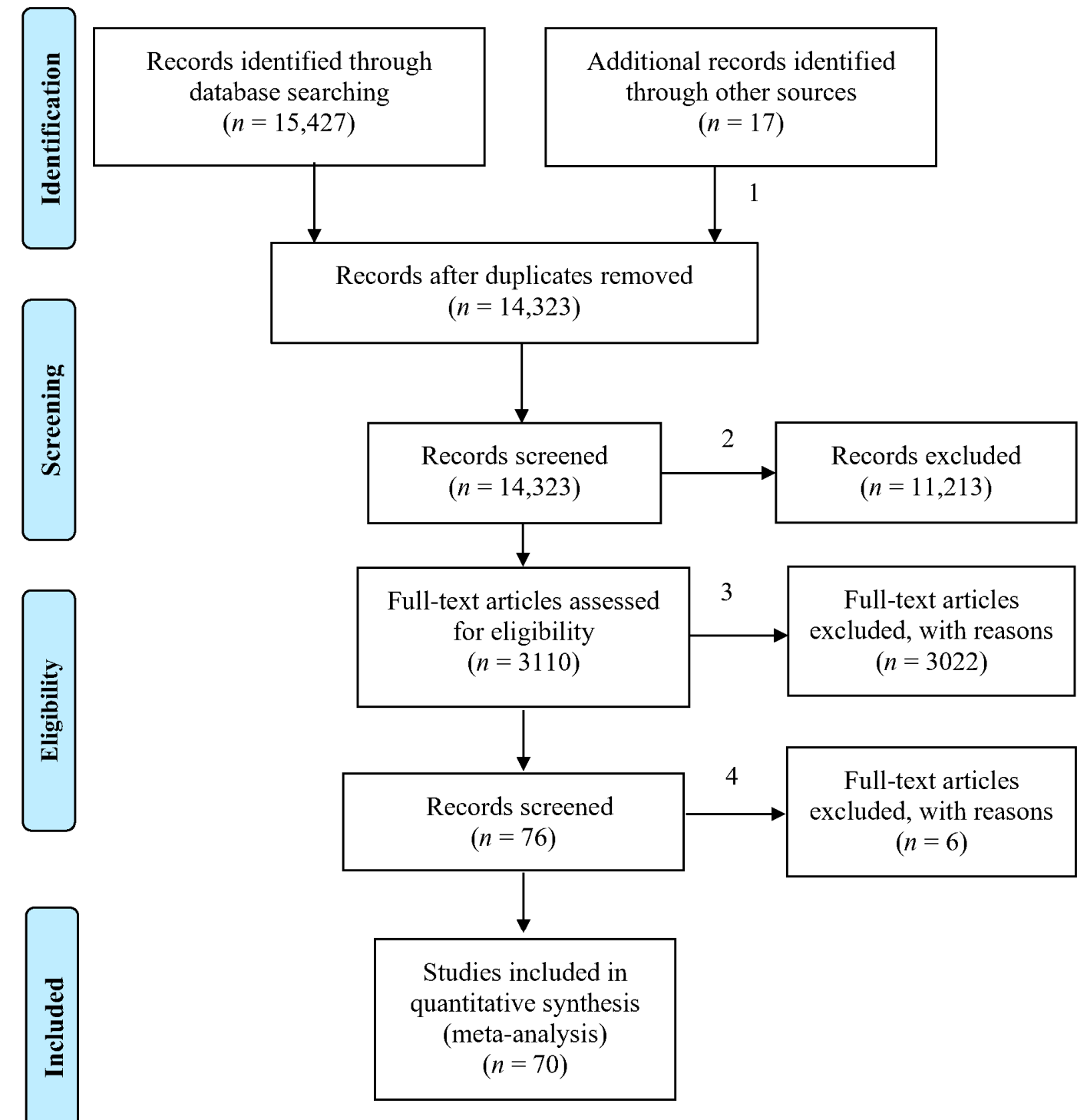

Figure 1. PRISMA 2009 Flow Diagram (PRISMA 2009 Flow Diagram. Note: (1) Contacted the studies' corresponding authors without providing needed information and searched through the reference lists of the located studies; (2) articles that were not quantitative studies and those without theoretical variables concerning the determinants and compliance or intentions of cancer screening were filtered out; (3) articles without reporting complete zero-order correlations among the independent variables and dependent variables were filtered out; and (4) the articles on prostate cancer and one study with a large sample size were removed because the United States Preventative Services Task Force (USPSTF) recommendations for prostate cancer screening have changed).

\subsection{Procedures}

Overall, there were five steps in the present study (see Figure 2). Step 1 through Step 4 form Stage 1 of the so-called two-stage MASEM approach, leaving Step 5 in Stage 2. However, unlike Cheung and Chan [65], who assumed that all studies have the same population correlation matrices based on fixed-effects models [66], the present study estimated the heterogeneity using a homogeneity statistic $Q$ [67-70] in Stage 1 [71]. In the absence of homogeneity, the random-effects model (as opposed to a fixed-effects model, which assumes that the true effect is the same for all studies), which allows the true effect to vary across studies, was used $[68,69,72]$. Furthermore, we accounted for variability in heterogeneous effect sizes by relating them to the studies' coded attributes; that is, the pooled correlation matrix is adjusted by the moderator effect. The fitted models were 
estimated based on the Akaike information criterion (AIC), followed by the QE (test statistic of residual heterogeneity) and QM (omnibus test statistic of the significance of moderators) statistics.

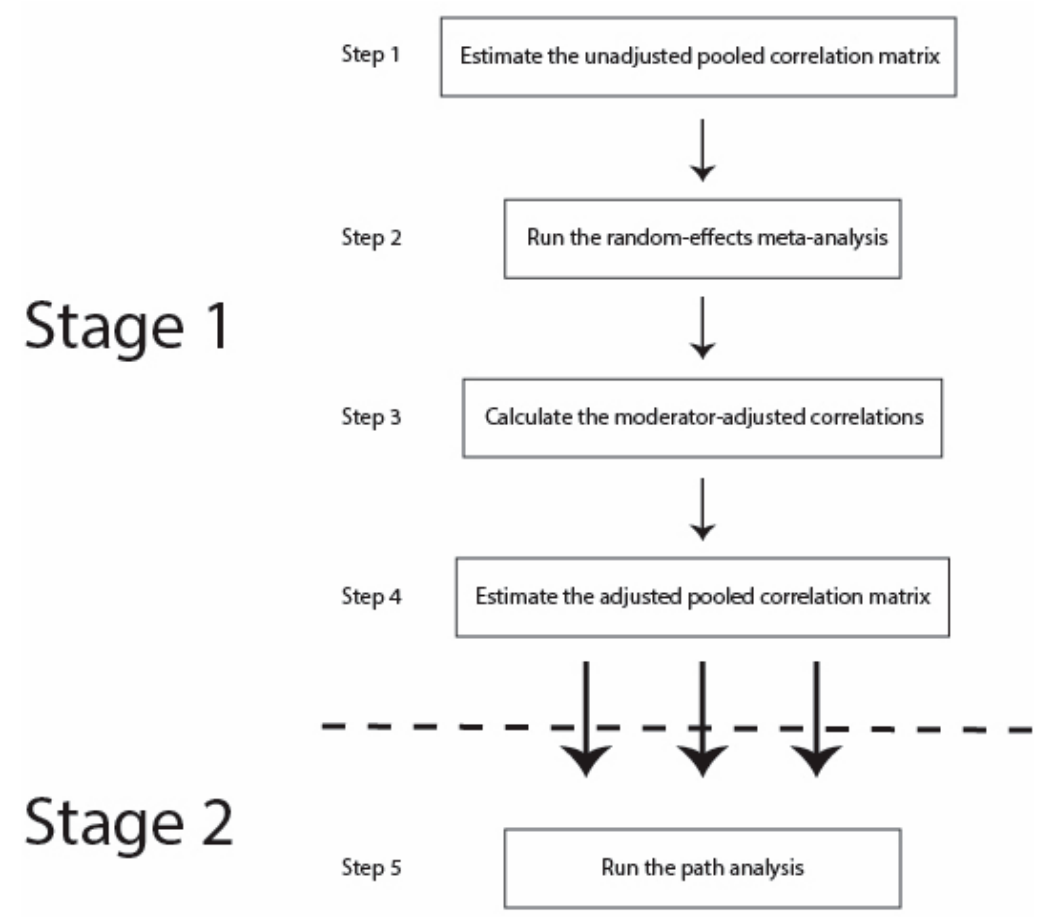

Figure 2. Procedures of MASEM.

In addition, the compilation of effect sizes showed a clear hierarchical structure, as there were multiple effect sizes for many studies. Consequently, to sidestep the dependence problem among the effect sizes, we analyzed these data with multilevel mixed-effects modeling using the metafor package (version 2.10) of the R language (version 3.51) [73], which is generally superior to other approaches, e.g., robust variance estimation and averaging effect sizes $[59,74,75]$. It should be noted that this practice in Stage 1 is also different from the procedure proposed by Cheung $[65,76]$.

The two-stage MASEM approach that the present study performs consists of the following five steps:

Step 1: The first step involves the estimation of a pooled correlation matrix of the relations. A matrix is constructed to represent the zero-order relations among all of the nine variables (see Table 1). The unadjusted pooled correlation matrix and the heterogeneity are estimated using the random-effects meta-analysis with the multilevel modeling approach. The cell number indicating the position of a particular correlation in the original correlation matrix is tested as a moderator in the model without the intercept. The resulting coefficients are the pooled correlation matrix.

Step 2: The next step is again to run the random-effects meta-analysis in the multilevel model with the intercept, taking into account the aforementioned study moderators.

Step 3: The resulting meta-regression coefficients and associated residual values in the above meta-regression model are used to calculate the moderator-adjusted correlations.

Step 4: Estimate the adjusted pooled correlation matrix in the same way as in Step 1 but replace the original correlation coefficients with the adjusted ones derived in Step 3.

Step 5: The path models involving the predictors of the intention and behavior based on the HBM and relevant theories based on the adjusted pooled correlation matrix are estimated using the weighted least squares (WLS) estimation (with 5000 parametric bootstrap replicates) of metaSEM [77]. 
Table 1. Pooled zero-order correlation matrix.

\begin{tabular}{llllllllll}
\hline & PBAR & PBEN & PBC & INT & PSEV & PSUS & CTA & CS & LIT \\
\hline PBAR & 1 & $51(53,317)$ & $73(64,065)$ & $86(62,920)$ & $31(19,138)$ & $45(41,254)$ & $44(33,560)$ & $129(67,178)$ & $65(38,460)$ \\
PBEN & $-0.123^{* * *}$ & 1 & $19(31,881)$ & $21(35,175)$ & $12(8412)$ & $20(25,018)$ & $12(15,568)$ & $20(18,416)$ & $19(9630)$ \\
PBC & $-0.09^{* * *}$ & $0.279^{* * *}$ & 1 & $32(39,986)$ & $8(6359)$ & $15(20,030)$ & $14(17,779)$ & $42(30,184)$ & $20(16,721)$ \\
INT & $-0.116^{* * *}$ & $0.267^{* * *}$ & $0.212^{* * *}$ & 1 & $10(5389)$ & $25(20,021)$ & $33(20,319)$ & $26(26,423)$ & $34(16,113)$ \\
PSEV & $-0.016^{* *}$ & $0.081^{* * *}$ & 0.009 & 0.029 & 1 & $10(7505)$ & $9(3922)$ & $16(6106)$ & $10(7344)$ \\
PSUS & $-0.043^{*}$ & $0.183^{* * *}$ & 0.038 & $0.181^{* * *}$ & $0.197^{* * *}$ & 1 & $9(9555)$ & $25(18,411)$ & $18(16,883)$ \\
CTA & $-0.086^{* * *}$ & $0.103^{*}$ & $0.087^{*}$ & $0.166^{* * *}$ & 0.01 & $0.16^{*}$ & 1 & $36(24,323)$ & $14(9225)$ \\
CS & $-0.147^{* * *}$ & $0.196^{* * *}$ & $0.164^{* * *}$ & $0.259^{* * *}$ & 0.031 & $0.071^{* *}$ & $0.167 * * *$ & 1 & $50(28,376)$ \\
LIT & $-0.05^{*}$ & $0.175^{* * *}$ & $0.172^{* * *}$ & $0.158^{* * *}$ & 0.008 & 0.045 & 0.072 & $0.145^{* * *}$ & 1 \\
\hline
\end{tabular}

Note: ${ }^{* * *} p<0.001,{ }^{* *} p<0.01,{ }^{*} p<0.05,{ }^{*} p<0.10$. CS = screening behavior; INT = intention; CTA = cues to action; LIT = health literacy; PBAR = perceived barriers; $\mathrm{PBC}=$ perceived behavioral control or self-efficacy; PBEN = perceived benefits; PSEV = perceived severity; and PSUS $=$ perceived susceptibility. The numbers shown in the upper triangular matrix represent the $\mathrm{k}$ (number of effect sizes) and the total sample size (within brackets).

\section{Results}

The multilevel modeling in Step 1 was performed to derive the pooled correlation matrix (shown in Table 1). The test for residual heterogeneity $(\mathrm{QE}(\mathrm{df}=1067)=21,928.921$, $p<0.001)$ and the test of moderators $(\mathrm{QM}(\mathrm{df}=36)=675.245, p<0.001)$ were both significant. The intraclass correlation (ICC) value is 0.157 , which indicates that $15.70 \%$ of the variance is attributable to the between-study variability. Based on the pooled correlation matrix derived from Step 1, the univariate effect sizes of interest, whose results correspond to the first research question, can be extracted. As shown in Table 1, there generally exist weak effect sizes for the predictors on screening intentions $\left(r_{b}=-0.116\right.$,

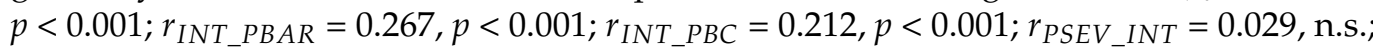
$\left.r_{\text {PSUS_INT }}=0.181, p<0.001 ; r_{C T A_{-} I N T}=0.166, p<0.001 ; r_{\text {LIT_INT }}=0.158, p<0.001\right)$. In addition, the effect sizes of the predictors on actual screening behavior showed similar results to those of the predicting intentions $\left(r_{C S \_P B A R}=-0.147, p<0.001 ; r_{C S \_P B E N}=0.196\right.$, $p<0.001 ; r_{C S \_P B C}=0.164, p<0.001 ; r_{C S \_P S E V}=0.031$, n.s.; $r_{C S \_P S U S}=0.071, p<0.01$; $\left.r_{C S \_C T A}=0.167, p<0.001 ; r_{L I T \_C S}=0.145, p<0.001 ; r_{C S \_I N T}=0.259, p<0.001\right)$. Subsequently, the forest plots (see Figure 3) indicating the estimated common effects as well as the intervals, visually display the results of Table 2. Furthermore, the funnel plots (see Figure 4), demonstrating possible publication bias, are also presented. According to the funnel plots based on the trim-and-fill analysis [78], publication bias may not be serious. Egger's regression test [79] also confirmed the conclusion ( $p$ s > 0.05).

None of these study moderators were found to be significant in Step 2 through Step 3. Consequently, Step 4 was skipped, and the unadjusted pooled correlation matrix generated in Step 1 was used in Step 5. Three models were tested and compared on their performance $\left(R^{2}\right)$. All variables directly predicted cancer-screening behavior in Model 1, while all variables predicted intentions and behavior simultaneously in Model 2. Model 2 was further simplified into Model 3, in which intentions fully mediated the effects of the independent variables on behavior. Through comparing changes in $R^{2}$, Model 3 was found to be superior to both Model 2 and Model 1. In Model 3, the $R^{2}$ values of behavior and intentions were 3\% (4\% in both Models 1 and 2 ) and 17\% (12\% in Model 2), respectively, which indicated a trivial amount of the explained variance of behavior but an acceptable amount of the explained variance of intentions. Furthermore, all of the fit indices of Model 3 met the cut-off criteria [80] $\left(\chi^{2}(7)=41.723, p<0.001\right.$, RMSEA (Root Mean Square Error of Approximation) $=0.011$, RMSEA $_{\text {lower } 95 \% \mathrm{CI}}=0.008, \mathrm{RMSEA}_{\text {upper } 95 \% \mathrm{CI}}=0.014$, SRMR (Standardized Root Mean Square Residual) =0.040, CFI (Comparative Fit Index) = 0.947, AIC $($ Akaike Information Criterion $)=27.723$, and BIC (Bayesian Information Criteria $)=$ $-32.807)$, indicating that the model fits the data well. It was found that the variable of intentions was only positively predicted by cues to action $(\beta \beta=0.236, p<0.001)$, health literacy $(\beta=0.138, p<0.001)$, and perceived susceptibility $(\beta=0.11, p<0.05)$ and that behavior was negatively predicted by intentions $(\beta=-0.130, p<0.001)$ (see Table 2$)$. All 
the other predictions were not significant. The total indirect effect was -0.149 , which means that all of the predictors had trivial negative effects on behavior through intentions.

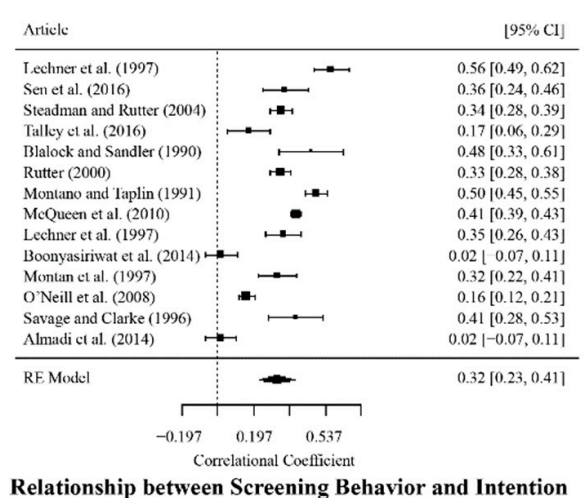

Relationship between Screening Behavior and Intention

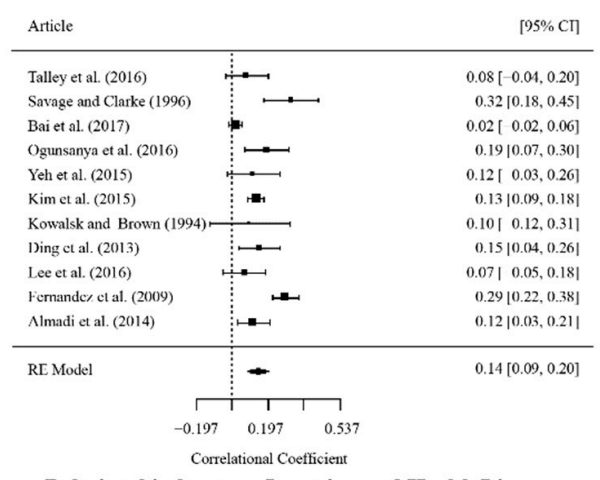

Relationship between Intention and Health Literacy

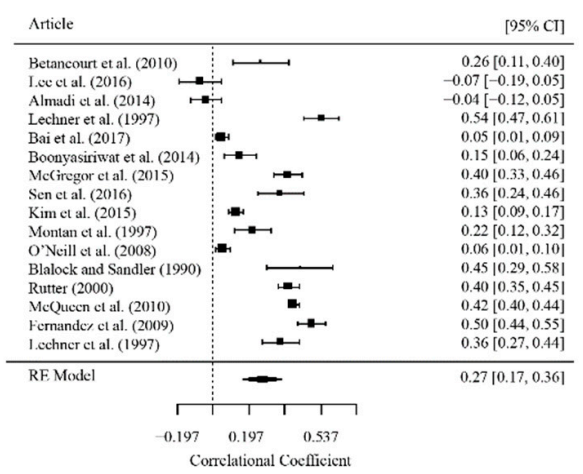

Relationship between Intention and

Perceived Behavioral Control

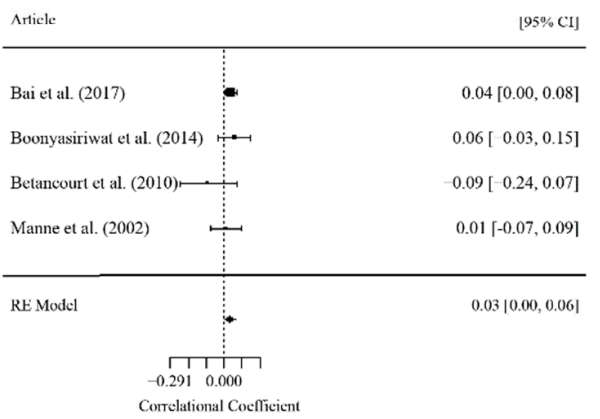

Relationship between Intention and Perceived Severity

\begin{tabular}{|c|c|c|}
\hline Article & & {$[95 \% \mathrm{Cl}]$} \\
\hline Yeh et al. (2015) & $\longrightarrow$ & $0.04[-0.10,0.19]$ \\
\hline Montan et al. (1997) & $\longmapsto$ & $0.30[0.20,0.39]$ \\
\hline McQueen et al. (2010) & - & $0.09|0.06,0.12|$ \\
\hline Almadi et al. (2014) & -1 & $0.02[-0.06,0.11]$ \\
\hline Boonyasiriwat et al. (2014 & $-\infty$ & $0.13[0.04,0.22]$ \\
\hline McGregor et al. (2015) & - & $0.34[0.27,0.41]$ \\
\hline Betancourt et al. (2010) & $\longmapsto$ & $0.24[0.09,0.38]$ \\
\hline Muliira et al. (2017) & — & $0.32[0.16,0.47]$ \\
\hline RE Model & - & $0.18[0.09,0.27]$ \\
\hline$\stackrel{\ulcorner}{\ulcorner}$ & \begin{tabular}{l|l}
\multicolumn{1}{|c|}{$\mid$} & \\
0.197 & 0.537
\end{tabular} & \\
\hline
\end{tabular}

Relationship between Intention and Cues to Action

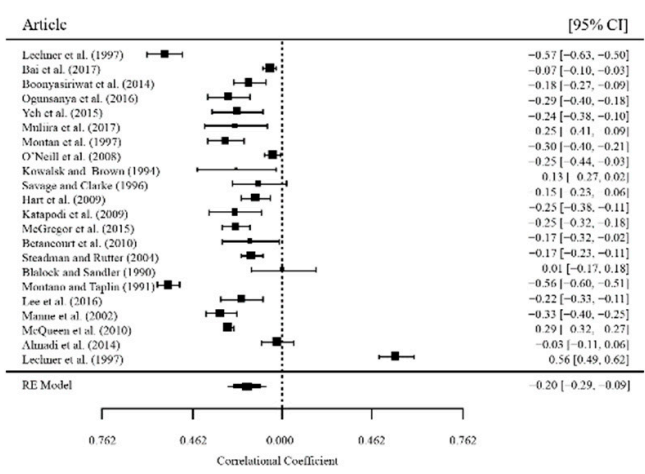

Relationship between Intention and Perceived Barriers

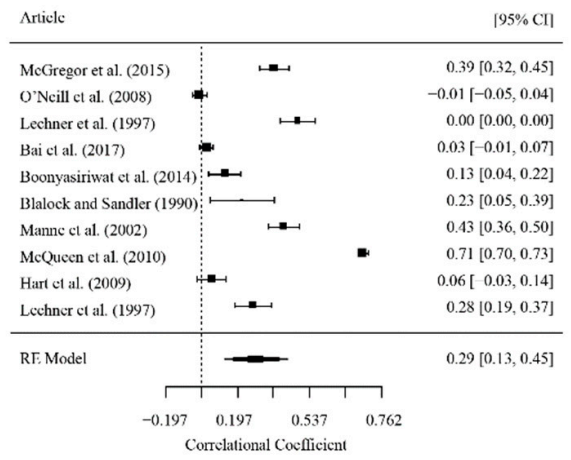

Relationship between Intention and Perceived Benefit

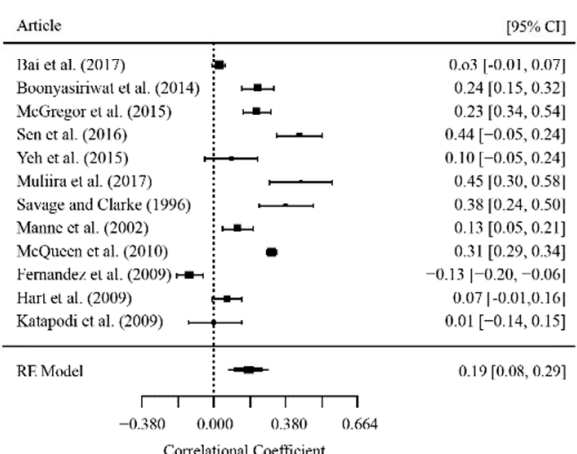

Relationship between Intention and Perceived Susceptibility

Figure 3. Forest plots [34,39,42,45,46,81-145]. 


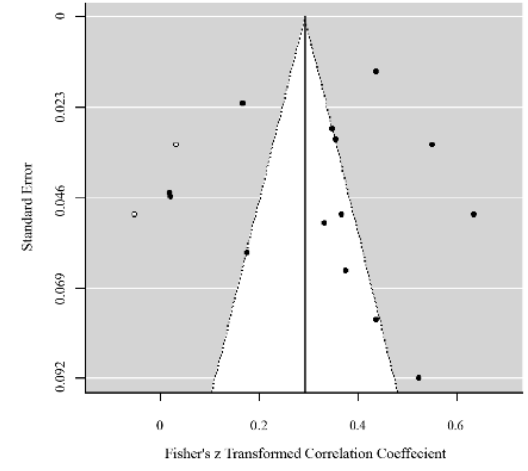

Relationship between Screening Behavior and Intention

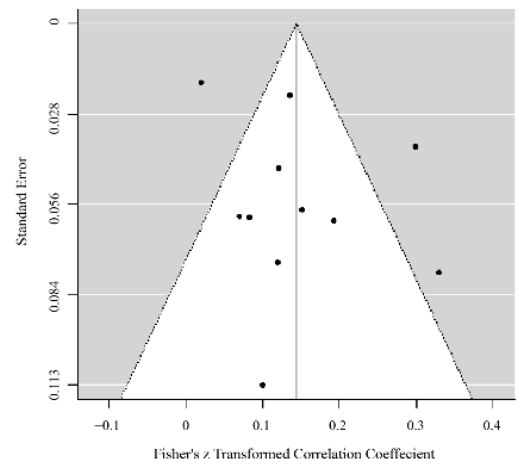

Relationship between Intention and Health Literacy

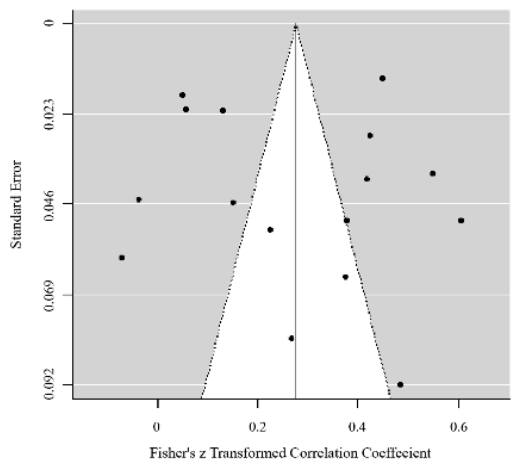

Relationship between Intention and Perceived Behavioral Control

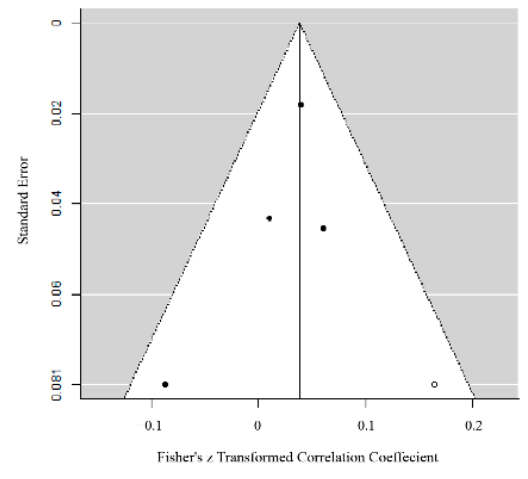

Relationship between Intention and Perceived Severity

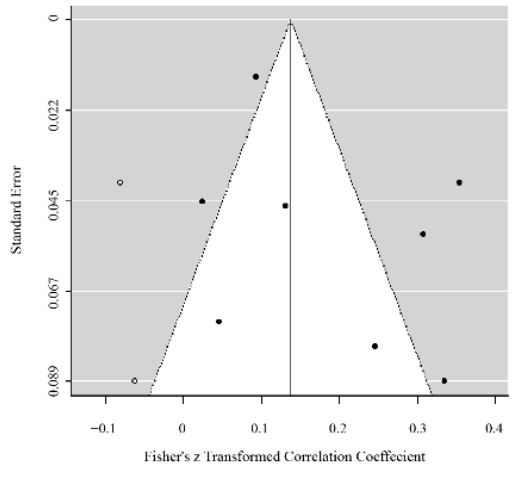

Relationship between Intention and Cues to Action

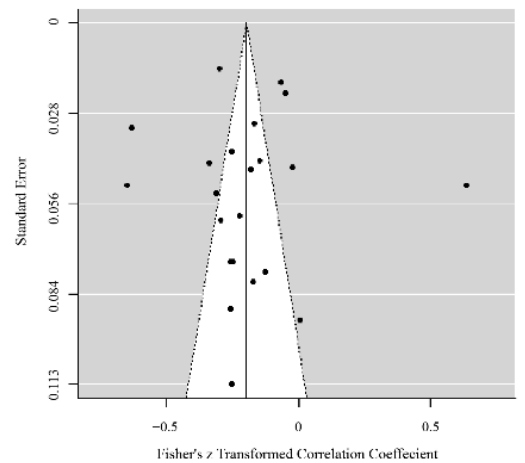

Relationship between Intention and Perceived Barriers

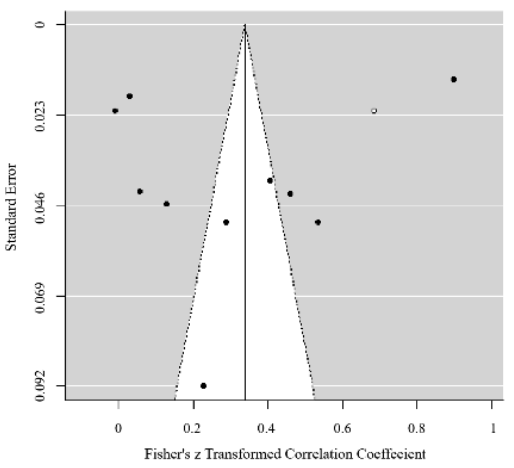

Relationship between Intention and Perceived Benefits

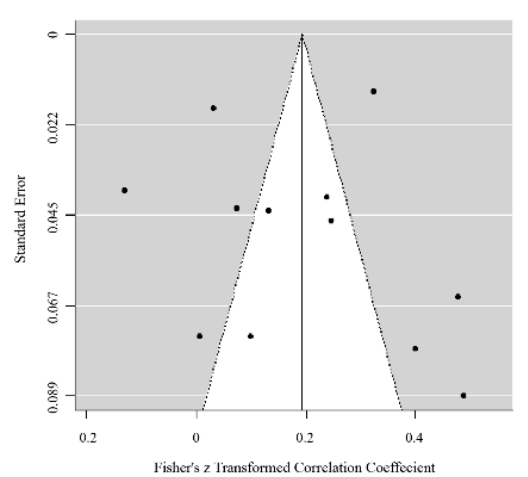

Relationship between intention and perceived susceptibility

Figure 4. Funnel plots (solid circles represent the weight of the studies, and empty circles represent the added studies). 
Table 2. Results of the WLS estimation using Metasem.

\begin{tabular}{lcccc}
\hline & Estimate & Std. Error & $\mathbf{z}$ Value & $\operatorname{Pr}(>|\mathbf{z}|)$ \\
\hline CS on INT & -0.13 & 0.041 & -3.203 & 0.001 \\
INT on CTA & 0.236 & 0.027 & 8.673 & 0 \\
INT on LIT & 0.138 & 0.035 & 3.981 & 0 \\
INT on PBAR & -0.012 & 0.047 & -0.253 & 0.801 \\
INT on PBC & -0.03 & 0.074 & -0.409 & 0.683 \\
INT on PBEN & 0.039 & 0.044 & 0.903 & 0.367 \\
INT on PSEV & 0.093 & 0.071 & 1.319 & 0.187 \\
INT on PSUS & 0.11 & 0.056 & 1.972 & 0.049 \\
\hline
\end{tabular}

Note: $n=42,071, \chi^{2}(7)=41.723, p<0.001$, RMSEA $=0.011$, RMSEA $_{\text {lower } 95 \% \text { CI }}=0.008$, RMSEA $_{\text {upper } 95 \% \mathrm{CI}}=0.014$ $\mathrm{SRMR}=0.040, \mathrm{TLI}=0.726, \mathrm{CFI}=0.947, \mathrm{AIC}=27.723$, and $\mathrm{BIC}=-32.807 . \mathrm{CS}=$ screening behavior; $\mathrm{INT}=$ intention; $\mathrm{CTA}=$ cues to action; $\mathrm{LIT}=$ health literacy; $\mathrm{PBAR}=$ perceived barriers; $\mathrm{PBC}=$ perceived behavioral control or self-efficacy; PBEN = perceived benefits; PSEV = perceived severity; and PSUS = perceived susceptibility.

\section{Discussion}

\subsection{Discussion of Estimation Results}

We found that the individual importance of predictors of the health belief model (HBM) is unequal through MASEM. Cues to action, health literacy, and perceived susceptibility are the significant determinants of cancer-screening intention. The long-believed core components of the HBM, i.e., perceived barriers, perceived benefits, and perceived severity, played a marginal role in predicting intention. In addition, the added variable, i.e., perceived behavioral control, was also not a significant predictor of intention. This finding is generally consistent with the synthesis of Janz and Becker [57], who found that perceived benefits and perceived severity were strong only for sick-role behaviors (SRB) and that perceived susceptibility was a stronger contributor for explaining preventive-health behaviors (PHB) than SRB.

The finding of the three key predictors of screening intention demonstrates that internal cues to action (e.g., feeling hurt or other symptoms of getting cancer) and perceived susceptibility are directly related to immediate personal vulnerability or the probability of getting cancer. Moreover, internal cues and perceived vulnerability may be triggered or primed by external cues to action (e.g., the doctor's warnings or a close relative's death due to cancer). Furthermore, there is no salient or discernible imminent threat or risk without sufficient awareness and knowledge, i.e., health literacy [32].

Conversely, the insignificant effects of perceived barriers, perceived benefits, and perceived severity on screening intention indicate that general outcome expectancies or beliefs about screening benefits and barriers are too general and distant to concern and urge people [146], who do not act until they realize they are in real danger. The factor of perceived behavioral control or self-efficacy is not important to predict intention. Such a finding shows that the intended uptake of screening has nothing to do with ability, which is emphasized in the studies based on the theory of planned behavior (TPB). This finding implies that the application area of intentions may moderate the effects of the TPB predictors, and future research should examine such a hypothesis.

\subsection{Gap between Health Intentions and Health Behaviors}

This study found that the gap between intention and behavior is real, and this result is also consistent with part of the prior findings [147]. For instance, some researchers [54,56,83] found that the health belief model (HBM) was weakly predictive of behavior in comparison with social cognitive theories, such as the theory of planned behavior (TPB) and the theory of reasoned action (TRA) [55]. The present study has further discovered that the determinants of both intentions and behavior embodied in the TRA and the TPB also only partially predict intentions [148] and that the performance of a behavior is not as simple as a natural outcome of intentions [146,149]. The HBM (as well as other value-expectancy-based theories) is better represented as an effect of health beliefs on health intentions rather than behavior and hence is hardly a behavior prediction theory. 
There are two possible paths to improve the prediction of behavior. The first is to strictly stick to the original or reconsider both the conceptualization and operationalization of factors encompassed in these theories. For instance, attitudes, subjective norms, and perceived behavioral control were often incorrectly directly measured and tested in many applied studies. In addition, as Fishbein and Cappella [146] pointed out, specific instead of general beliefs associated with screening characteristics ultimately underlie and determine intentions and behaviors. Some crucial determinants of health behavior have been notably unheeded in the literature, and hence they may be included to translate intentions into behavior. For instance, Gollwitzer [150,151] proposed the implementation of intentions to improve the prediction of actual behavior while arguing that individuals pass control to the environment, which acts as a cue to action. When cues are present, the performance of the intended behavior ensues [150]. Fishbein [146,149] incorporated actual ability and environmental factors to predict behaviors in addition to intentions. Wakefield, Loken and Hornik [9] underscored policy support. Furthermore, screening intentions may be temporal and situational [148]. Consequently, some authors [152,153] combined the HBM and the transtheoretical model (TTM) (or stages of change) in their screening research, whereas others [154] further incorporated the dual-process model in the combination of the HBM and TTM. Moreover, suggesting a distinction between pre-intentional motivation processes that lead to a behavioral intention and post-intentional volition processes that lead to actual behavior, Schwarzer and his associates $[155,156]$ proposed the health action process approach (HAPA) by incorporating three post-intentional factors (planning, maintenance self-efficacy, and action control) to the expanded HBM. These efforts are commendable, but the effect should also be amenable to a model-based meta-analysis.

\section{Implications}

\subsection{Theoretical Implications}

Given the estimation results of path analysis, a model predicting screening intentions, termed the health intention model, is proposed (see Figure 5). Our proposed model is much more parsimonious (only retains the two original variables, i.e., cues to action and perceived susceptibility) than the HBM and slightly expands the HBM through the addition of health literacy. The model was tested with a perfect model fit (the RMSEA and RSMR were $\sim 0$, and the CFI was $\sim 1$ ), and all predictors had significant positive effects on intentions (ps $<0.001, R^{2}=13 \%$ ). Although the proposed parsimonious model is open to further tests, it has a very similar explanatory power to the complex HBM, albeit with significant predictions on intentions using the collective data source. Consequently, the present study has significantly advanced the development of theories on cancer-screening intentions.

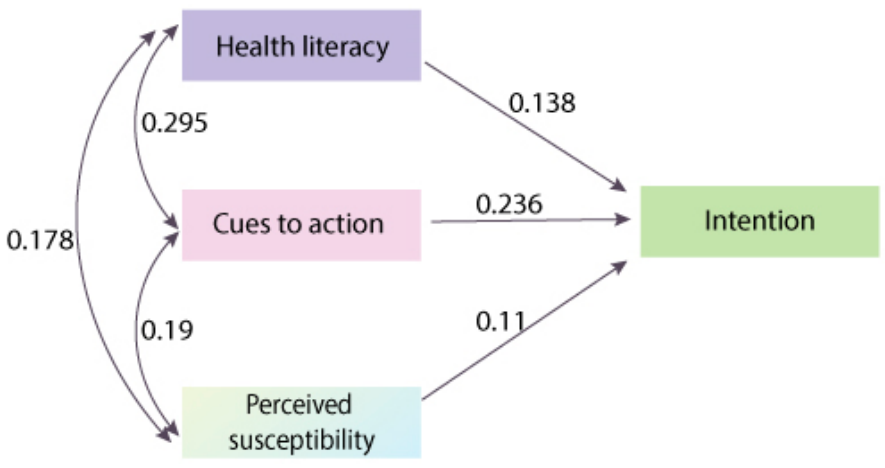

Figure 5. The health intention model.

\subsection{Practical and Methodological Implications}

The findings also have profound practical implications. Health communication campaigns should focus on enlightening and engaging the public through all necessary means to raise awareness and transfer knowledge in relation to screening procedures as well as can- 
cers per se. Nevertheless, the downside of the finding is that the knowledge gap [157] or inequality in health literacy is pervasive among ethnicities and various social strata $[158,159]$ and is hence a thorny worldwide problem to tackle. Therefore, to improve universal health literacy, health communication has a long way to go.

To our knowledge, the present paper is one of the very few model-based metaanalytical studies in health communication, although Eisend [160] briefly summarized the gist of MASEM, and James [161] applied MASEM in an interdisciplinary journal. This study has also discovered the limitations of the HBM and other similar value-expectancybased theories in predicting cancer-screening intentions and behavior. As a result of this finding, a parsimonious model is proposed, and other remedies to the existing models are also discussed. Moreover, effective health communication strategies and interventions are suggested. Therefore, the present study has made substantial theoretical, methodological, and practical contributions to health communication.

\section{Limitations and Future Research Directions}

This study has limitations. Since the model-based meta-analysis requires complete correlations, some meaningful predictors, such as trust in health providers, social capital, and demographics, were removed in the present study. This constraint has prevented us from exploring more possibilities of theory testing as well as advancement. An additional limitation results from the developmental nature of the model-based meta-analysis methodology, whose algorithms and software packages are works in progress. As a result, some forms of theoretical explorations may not be available.

Moreover, we only considered the studies that examined the positive cancer-screening intentions and behaviors but neglected those that studied overscreening behaviors. Nevertheless, overscreening has psychological and social implications [162]. A future metaanalysis should include studies in the two separate lines of research and ideally examine the differences in predictors and effect sizes.

Author Contributions: Conceptualization, G.C.F.; methodology, G.C.F.; software, G.C.F.; validation, G.C.F., Z.L. and X.S.; formal analysis, G.C.F.; resources, Q.Y.; data curation, G.C.F., W.O., X.S., and Z.L.; writing—original draft preparation, G.C.F.; writing—review and editing, G.C.F.; visualization, G.C.F. and Z.L.; supervision, G.C.F.; project administration, G.C.F.; funding acquisition, G.C.F. All authors have read and agreed to the published version of the manuscript.

Funding: This research was funded by National Social Science Foundation of China, grant number 18BXW082 and The APC was funded by Fund for the Distinguished Professor Team of Shenzhen University, grant number 860-0000020717.

Institutional Review Board Statement: Not applicable.

Informed Consent Statement: Not applicable.

Conflicts of Interest: The authors declare no conflict of interest.

\section{References}

1. WHO. WHO ICancer. Available online: https://www.who.int/news-room/fact-sheets/detail/cancer (accessed on 21 February 2021).

2. American Cancer Society. Cancer Facts \& Figures 2021. Available online: https://www.cancer.org/content/dam/cancer-org/re search/cancer-facts-and-statistics/annual-cancer-facts-and-figures/2021/cancer-facts-and-figures-2021.pdf (accessed on 21 February 2021).

3. Ogden, J. Health Psychology; McGraw-Hill: London, UK, 2012.

4. Rex, D.K.; Johnson, D.A.; Lieberman, D.A.; Burt, R.W.; Sonnenberg, A. Colorectal cancer prevention 2000: Screening recommendations of the American College of Gastroenterology. Am. J. Gastroenterol. 2000, 95, 868. [CrossRef]

5. National Lung Screening Trial Research Team. Reduced lung-cancer mortality with low-dose computed tomographic screening. N. Engl. J. Med. 2011, 365, 395-409. [CrossRef]

6. Faivre, J.; Dancourt, V.; Lejeune, C.; Tazi, M.A.; Lamour, J.; Gerard, D.; Dassonville, F.; Bonithon-Kopp, C. Reduction in colorectal cancer mortality by fecal occult blood screening in a French controlled study. Gastroenterology 2004, 126, 1674-1680. [CrossRef] 
7. USPSTF. Published Recommendations-US Preventive Services Task Force. Available online: https://www.uspreventiveservices taskforce.org/BrowseRec/Index/browse-recommendations (accessed on 21 February 2021).

8. National Cancer Institute. Cancer Screening. Available online: https:/ / www.cancer.gov/about-cancer/screening (accessed on 21 February 2021).

9. Wakefield, M.A.; Loken, B.; Hornik, R.C. Use of mass media campaigns to change health behaviour. Lancet 2010, 376, 1261-1271. [CrossRef]

10. Sung, J.J.Y.; Lau, J.Y.W.; Young, G.P.; Sano, Y.; Chiu, H.M.; Byeon, J.S.; Yeoh, K.G.; Goh, K.L.; Sollano, J.; Rerknimitr, R.; et al. Asia Pacific consensus recommendations for colorectal cancer screening. Gut 2008, 57, 1166. [CrossRef]

11. Smith Robert, A.; Brooks, D.; Cokkinides, V.; Saslow, D.; Brawley Otis, W. Cancer screening in the United States, 2013. CA Cancer J. Clin. 2013, 63, 87-105. [CrossRef]

12. Vernon, S.W.; Laville, E.A.; Jackson, G.L. Participation in breast screening programs: A review. Soc. Sci. Med. 1990, 30, 1107-1118. [CrossRef]

13. Gracie, K.; Kennedy, M.; Robson, J.; Callister, M. S131 What proportion of the uk population would be eligible for ct screening for lung cancer according to various proposed inclusion criteria? Thorax 2016, 71, A78. [CrossRef]

14. Hart, A.R.; Barone, T.L.; Mayberry, J.F. Increasing compliance with colorectal cancer screening: The development of effective health education. Health Educ. Res. 1997, 12, 171-180. [CrossRef] [PubMed]

15. Elobaid, Y.E.; Aw, T.C.; Grivna, M.; Nagelkerke, N. Breast Cancer Screening Awareness, Knowledge, and Practice among Arab Women in the United Arab Emirates: A Cross-Sectional Survey. PLoS ONE 2014, 9, e105783. [CrossRef]

16. Azubuike, S.O.; Okwuokei, S.O. Knowledge, Attitude and Practices of Women Towards Breast Cancer in Benin City, Nigeria. Ann. Med. Health Sci. Res. 2013, 3, 155-160. [CrossRef] [PubMed]

17. O'Malley, M.S.; Earp, J.A.; Hawley, S.T.; Schell, M.J.; Mathews, H.F.; Mitchell, J. The association of race/ethnicity, socioeconomic status, and physician recommendation for mammography: Who gets the message about breast cancer screening? Am. J. Public Health 2001, 91, 49-54. [CrossRef] [PubMed]

18. Rodríguez, M.A.; Ward, L.M.; Pérez-Stable, E.J. Breast and Cervical Cancer Screening: Impact of Health Insurance Status, Ethnicity, and Nativity of Latinas. Ann. Fam. Med. 2005, 3, 235-241. [CrossRef] [PubMed]

19. Maheswaran, R.; Pearson, T.; Jordan, H.; Black, D. Socioeconomic deprivation, travel distance, location of service, and uptake of breast cancer screening in North Derbyshire, UK. J. Epidemiol. Community Health 2006, 60, 208. [CrossRef] [PubMed]

20. Lim, J.N.; Ojo, A.A. Barriers to utilisation of cervical cancer screening in Sub Sahara Africa: A systematic review. Eur. J. Cancer Care 2017, 26, e12444. [CrossRef] [PubMed]

21. Klabunde, C.N.; Vernon, S.W.; Nadel, M.R.; Breen, N.; Seeff, L.C.; Brown, M.L. Barriers to colorectal cancer screening: A comparison of reports from primary care physicians and average-risk adults. Med. Care 2005, 43, 939-944. [CrossRef] [PubMed]

22. Prentice-Dunn, S.; Rogers, R.W. Protection motivation theory and preventive health: Beyond the health belief model. Health Educ. Res. 1986, 1, 153-161. [CrossRef]

23. Kelly, J.A.; Murphy, D.A.; Sikkema, K.J.; Kalichman, S.C. Psychological interventions to prevent HIV infection are urgently needed: New priorities for behavioral research in the second decade of AIDS. Am. Psychol. 1993, 48, 1023-1034. [CrossRef]

24. Michie, S.; Prestwich, A. Are interventions theory-based? Development of a theory coding scheme. Health Psychol. 2010, 29, 1-8. [CrossRef]

25. Kuhn, T.S. The Structure of Scientific Revolutions; University of Chicago Press: Chicago, IL, USA, 1970.

26. Rosenstock, I.M. Why People Use Health Services. Milbank Meml. Fund Q. 1966, 44, 94-127. [CrossRef]

27. Rosenstock, I.M. Public response to cancer screening and detection programs. Determinants of health behavior. J. Chronic Dis. 1963, 16, 407-418. [CrossRef]

28. Ajzen, I.; Fishbein, M. Understanding Attitudes and Predicting Social Behavior; Prentice-Hall: Englewood Cliffs, NJ, USA, 1980.

29. Fishbein, M.; Ajzen, I. Belief, Attitude, Intention, and Behavior: An Introduction to Theory and Research; Addison-Wesley Pub. Co.: Reading, MA, USA, 1975.

30. Ajzen, I. From Intentions to Actions: A Theory of Planned Behavior. In Action Control: From Cognition to Behavior; Kuhl, J., Beckmann, J., Eds.; Springer: Berlin/Heidelberg, Germany, 1985; pp. 11-39.

31. Hochbaum, G.; Rosenstock, I.; Kegels, S. Health Belief Model; United States Public Health Services: Washington, DC, USA, 1952.

32. Rosenstock, I.M. Historical Origins of the Health Belief Model. Health Educ. Monogr. 1974, 2, 328-335. [CrossRef]

33. Rosenstock, I.M. The Health Belief Model and Preventive Health Behavior. Health Educ. Monogr. 1974, 2, 354-386. [CrossRef]

34. Aiken, L.S.; West, S.G.; Woodward, C.K.; Reno, R.R. Health beliefs and compliance with mammography-screening recommendations in asymptomatic women. Health Psychol. 1994, 13, 122. [CrossRef]

35. Katapodi, M.C.; Northouse, L.L.; Schafenacker, A.M.; Duquette, D.; Duffy, S.A.; Ronis, D.L.; Anderson, B.; Janz, N.K.; McLosky, J.; Milliron, K.J.; et al. Using a state cancer registry to recruit young breast cancer survivors and high-risk relatives: Protocol of a randomized trial testing the efficacy of a targeted versus a tailored intervention to increase breast cancer screening. BMC Cancer 2013, 13, 97. [CrossRef]

36. Ronis, D.L. Conditional health threats: Health beliefs, decisions, and behaviors among adults. Health Psychol. 1992, 11, 127. [CrossRef]

37. Bandura, A. Self-Efficacy: Toward a Unifying Theory of Behavioral Change. Psychol. Rev. 1977, 84, 191-215. [CrossRef] 
38. Rosenstock, I.M.; Strecher, V.J.; Becker, M.H. Social learning theory and the Health Belief Model. Health Educ. Q. 1988, 15, 175-183. [CrossRef]

39. Montaño, D.E.; Thompson, B.; Taylor, V.M.; Mahloch, J. Understanding mammography intention and utilization among women in an inner city public hospital clinic. Prev. Med. 1997, 26, 817-824. [CrossRef]

40. Ogunsanya, M.E.; Brown, C.M.; Odedina, F.T.; Barner, J.C.; Corbell, B.; Adedipe, T.B. Beliefs Regarding Prostate Cancer Screening Among Black Males Aged 18 to 40 Years. Am. J. Men's Health 2017, 11, 41-53. [CrossRef]

41. Mary, G. The Influence of Spirituality and Religiosity on Breast Cancer Screening Delay in African American Women: Application of the Theory of Reasoned Action and Planned Behavior (TRA/TPB). J. Assoc. Black Nurs. Fac. High. Educ. 2006, 17, 89.

42. Montano, D.E.; Taplin, S.H. A test of an expanded theory of reasoned action to predict mammography participation. Soc. Sci. Med. 1991, 32, 733-741. [CrossRef]

43. Sieverding, M.; Matterne, U.; Ciccarello, L. What Role Do Social Norms Play in the Context of Men's Cancer Screening Intention and Behavior? Application of an Extended Theory of Planned Behavior. Health Psychol. 2010, 29, 72-81. [CrossRef] [PubMed]

44. Roncancio, A.M.; Ward, K.K.; Sanchez, I.A.; Cano, M.A.; Byrd, T.L.; Vernon, S.W. Using the Theory of Planned Behavior to Understand Cervical Cancer Screening Among Latinas. Health Educ. Behav. 2015. [CrossRef] [PubMed]

45. O'Neill, S.C.; Bowling, J.M.; Brewer, N.T.; Lipkus, I.M.; Skinner, C.S.; Strigo, T.S.; Rimer, B.K. Intentions to maintain adherence to mammography. J. Women's Health 2008, 17, 1133-1141. [CrossRef]

46. Steadman, L.; Rutter, D.R. Belief importance and the theory of planned behaviour: Comparing modal and ranked modal beliefs in predicting attendance at breast screening. Br. J. Health Psychol. 2004, 9, 447-463. [CrossRef]

47. Gaston, G.; Gerjo, K. The Theory of Planned Behavior: A Review of its Applications to Health-Related Behaviors. Am. J. Health Promot. 1996, 11, 87-98. [CrossRef]

48. Conner, M.; Armitage, C.J. Extending the Theory of Planned Behavior: A Review and Avenues for Further Research. J. Appl. Soc. Psychol. 1998, 28, 1429-1464. [CrossRef]

49. Ajzen, I. The theory of planned behavior. Organ. Behav. Hum. Decis. Process. 1991, 50, 179-211. [CrossRef]

50. Fisher, J.D.; Fisher, W.A.; Bryan, A.D.; Misovich, S.J. Information-motivation-behavioral skills model-based HIV risk behavior change intervention for inner-city high school youth. Health Psychol. 2002, 21, 177. [CrossRef]

51. Glass, G.V.; Smith, M.L.; McGaw, B. Meta-Analysis in Social Research; Sage Publications, Incorporated: Thousand Oaks, CA, USA, 1981.

52. Hunter, J.E.; Schmidt, F.L.; Jackson, G.B. Meta-Analysis: Cumulating Research Findings Across Studies; Sage Publications, Inc.: Thousand Oaks, CA, USA, 1982; Volume 4.

53. Rosenthal, R. Meta-Analytic Procedures for Social Research; Sage: Newbury Park, CA, USA, 1991; Volume 6.

54. Harrison, J.A.; Mullen, P.D.; Green, L.W. A meta-analysis of studies of the Health Belief Model with adults. Health Educ. Res. 1992, 7, 107-116. [CrossRef]

55. Carpenter, C.J. A Meta-Analysis of the Effectiveness of Health Belief Model Variables in Predicting Behavior. Health Commun. 2010, 25, 661-669. [CrossRef]

56. Zimmerman, R.S.; Vernberg, D. Models of preventive health behavior: Comparison, critique, and meta-analysis. Adv. Med. Sociol. 1994, 4, 45-67.

57. Janz, N.K.; Becker, M.H. The health belief model: A decade later. Health Educ. Q. 1984, 11, 1-47. [CrossRef] [PubMed]

58. Milne, S.; Sheeran, P.; Orbell, S. Prediction and Intervention in Health-Related Behavior: A Meta-Analytic Review of Protection Motivation Theory. J. Appl. Soc. Psychol. 2000, 30, 106-143. [CrossRef]

59. Wilson, S.J.; Polanin, J.R.; Lipsey, M.W. Fitting Meta-Analytic Structural Equation Models with Complex Datasets. Res. Synth. Methods 2016, 7, 121-139. [CrossRef] [PubMed]

60. Becker, B.J. Model-based meta-analysis. In The Handbook of Research Synthesis and Meta-Analysis; Cooper, H., Hedges, L.V., Eds.; Russell Sage Foundation: New York, NY, USA, 2009; Volume 2, pp. 377-395.

61. McMillan, B.; Conner, M. Health cognition assessment. In Cambridge Handbook of Psychology, Health and Medicine; Ayers, A.B.S., McManus, C., Newman, S., Wallston, K., Weinman, J., West, R., Eds.; Cambridge University Press: Cambridge, UK, 2007; pp. 260-266.

62. Cheung, M.W.L.; Hong, R.Y. Applications of meta-analytic structural equation modelling in health psychology: Examples, issues, and recommendations. Health Psychol. Rev. 2017, 11, 265-279. [CrossRef]

63. Johnson, B.T.; Mullen, B.; Salas, E. Comparison of three major meta-analytic approaches. J. Appl. Psychol. 1995, 80, 94-106. [CrossRef]

64. Hofstede, G. The cultural relativity of the quality of life concept. Acad. Manag. Rev. 1984, 9, 389-398. [CrossRef]

65. Cheung, M.W.-L.; Chan, W. A Two-Stage Approach to Synthesizing Covariance Matrices in Meta-Analytic Structural Equation Modeling. Struct. Equ. Model. Multidiscip. J. 2009, 16, 28-53. [CrossRef]

66. Jak, S.; Cheung, M.W.L. Accounting for Missing Correlation Coefficients in Fixed-Effects MASEM. Multivar. Behav. Res. 2018, 53, 1-14. [CrossRef]

67. Hedges, L.V. Distribution theory for Glass's estimator of effect size and related estimators. J. Educ. Stat. 1981, 6, 107-128. [CrossRef]

68. Brockwell, S.E.; Gordon, I.R. A comparison of statistical methods for meta-analysis. Stat. Med. 2001, 20, 825-840. [CrossRef] 
69. Schmid, E.J.; Koch, G.G.; LaVange, L.M. An overview of statistical issues and methods of meta-analysis. J. Biopharm. Stat. 1991, 1, 103-120. [CrossRef] [PubMed]

70. Higgins, J.P.T.; Thompson, S.G. Quantifying heterogeneity in a meta-analysis. Stat. Med. 2002, 21, 1539-1558. [CrossRef] [PubMed]

71. Jak, S. Meta-Analytic Structural Equation Modelling; Springer: Cham, Switherlands, 2015. [CrossRef]

72. National Research Council. Combining Information: Statistical Issues and Opportunities for Research; National Academies: Washington, DC, USA, 1992; Volume 1.

73. Viechtbauer, W. Conducting meta-analyses in R with the metafor package. J. Stat. Softw. 2010, 36, 1-48. [CrossRef]

74. Moeyaert, M.; Ugille, M.; Natasha Beretvas, S.; Ferron, J.; Bunuan, R.; Van den Noortgate, W. Methods for dealing with multiple outcomes in meta-analysis: A comparison between averaging effect sizes, robust variance estimation and multilevel meta-analysis. Int. J. Soc. Res. Methodol. 2017, 20, 559-572. [CrossRef]

75. Berkey, C.S.; Hoaglin, D.C.; Antczak-Bouckoms, A.; Mosteller, F.; Colditz, G.A. Meta-analysis of multiple outcomes by regression with random effects. Stat. Med. 1998, 17, 2537-2550. [CrossRef]

76. Cheung, M.W.L. Meta-Analysis: A Structural Equation Modeling Approach; John Wiley \& Sons, Inc.: Chichester, UK, 2015.

77. Cheung, M.W.-L. metaSEM: An R package for meta-analysis using structural equation modeling. Front. Psychol. 2015, 5, 1521. [CrossRef] [PubMed]

78. Duval, S.; Tweedie, R. Trim and fill: A simple funnel-plot-based method of testing and adjusting for publication bias in meta-analysis. Biometrics 2000, 56, 455-463. [CrossRef] [PubMed]

79. Egger, M.; Smith, G.D.; Schneider, M.; Minder, C. Bias in meta-analysis detected by a simple, graphical test. BMJ 1997, $315,629$. [CrossRef] [PubMed]

80. Hu, L.T.; Bentler, P.M. Cutoff criteria for fit indexes in covariance structure analysis: Conventional criteria versus new alternatives. Struct. Equ. Model. Multidiscip. J. 1999, 6, 1-55. [CrossRef]

81. Abraido-Lanza, A.F.; Martins, M.C.; Shelton, R.C.; Florez, K.R. Breast Cancer Screening Among Dominican Latinas: A Closer Look at Fatalism and Oather Social and Cultural Factors. Health Educ. Behav. 2015, 42, 633-641. [CrossRef] [PubMed]

82. Abuadas, M.H.; Petro-Nustas, W.; Albikawi, Z.F.; Mari, M. Predictors of prostate cancer screening intention among older men in Jordan. Int. J. Urol. Nurs. 2017, 11, 31-41. [CrossRef]

83. Allahverdipour, H.; Emami, A. Perceptions of cervical cancer threat, benefits, and barriers of Papanicolaou smear screening programs for women in Iran. Women Health 2008, 47, 23-37. [CrossRef] [PubMed]

84. Almadi, M.A.; Mosli, M.H.; Bohlega, M.S.; Al Essa, M.A.; AlDohan, M.S.; Alabdallatif, T.A.; AlSagri, T.Y.; Algahtani, F.A.; Mandil, A. Effect of Public Knowledge, Attitudes, and Behavior on Willingness to Undergo Colorectal Cancer Screening Using the Health Belief Model. Saudi J. Gastroenterol. 2015, 21, 71-77. [CrossRef] [PubMed]

85. Amador, J.A.; Flynn, P.M.; Betancourt, H. Cultural beliefs about health professionals and perceived empathy influence continuity of cancer screening following a negative encounter. J. Behav. Med. 2015, 38, 798-808. [CrossRef] [PubMed]

86. Ayres, C.G.; Atkins, R.; Lee, J.H. Factors Related to Health Practices: Cervical Cancer Screening Among Filipino Women. Res. Theory Nurs. Pract. 2010, 24, 197-208. [CrossRef]

87. Bai, Y.; Liu, Q.; Chen, X.; Gao, Y.; Gong, H.; Tan, X.; Zhang, M.; Tuo, J.; Zhang, Y.; Xiang, Q.; et al. Protection motivation theory in predicting intention to receive cervical cancer screening in rural Chinese women. Psycho Oncol. 2017, 27, 442-449. [CrossRef]

88. Ben-Natan, M.; Adir, O. Screening for cervical cancer among Israeli lesbian women. Int. Nurs. Rev. 2009, 56, 433-441. [CrossRef] [PubMed]

89. Benjamins, M.R.; Ellison, C.G.; Krause, N.M.; Marcum, J.P. Religion and preventive service use: Do congregational support and religious beliefs explain the relationship between attendance and utilization? J. Behav. Med. 2011, 34, 462-476. [CrossRef] [PubMed]

90. Betancourt, H.; Flynn, P.M.; Riggs, M.; Garberoglio, C. A cultural research approach to instrument development: The case of breast and cervical cancer screening among Latino and Anglo women. Health Educ. Res. 2010, 25, 991-1007. [CrossRef]

91. Bleiker, E.M.; van der Ploeg, H.M.; Mook, J.; Kleijn, W.C. Anxiety, anger, and depression in elderly women. Psychol. Rep. 1993, 72, 567-574. [CrossRef] [PubMed]

92. Boonyasiriwat, W.; Hung, M.; Hon, S.D.; Tang, P.; Pappas, L.M.; Burt, R.W.; Schwartz, M.D.; Stroup, A.M.; Kinney, A.Y. Intention to Undergo Colonoscopy Screening Among Relatives of Colorectal Cancer Cases: A Theory-Based Model. Ann. Behav. Med. 2014, 47, 280-291. [CrossRef]

93. Boyer, B.A.; Cantor, R.K. Posttraumatic stress among women with breast cancer and their daughters: Relationship with daughters' breast cancer screening. Am. J. Fam. Ther. 2005, 33, 443-460. [CrossRef]

94. Brandt, H.M.; Dolinger, H.R.; Sharpe, P.A.; Hardin, J.W.; Berger, F.G. Relationship of colorectal cancer awareness and knowledge with colorectal cancer screening. Colorectal Cancer 2012, 1, 383-396. [CrossRef]

95. Brittain, K.; Murphy, V.P. Sociocultural and health correlates related to colorectal cancer screening adherence among urban African Americans. Cancer Nurs. 2015, 38, 118. [CrossRef]

96. Brown, W.M.; Consedine, N.S.; Magai, C. Time spent in the United States and breast cancer screening behaviors among ethnically diverse immigrant women: Evidence for acculturation? J. Immigr. Minority Health 2006, 8, 347-358. [CrossRef] [PubMed]

97. Consedine, N.S.; Magai, C.; Neugut, A.I. The contribution of emotional characteristics to breast cancer screening among women from six ethnic groups. Prev. Med. 2004, 38, 64-77. [CrossRef] 
98. Consedine, N.S.; Morgenstern, A.H.; Kudadjie-Gyamfi, E.; Magai, C.; Neugut, A.I. Prostate cancer screening behavior in men from seven ethnic groups: The fear factor. Cancer Epidemiol. Biomark. Prev. 2006, 15, 228-237. [CrossRef] [PubMed]

99. Dean, L.T.; Subramanian, S.V.; Williams, D.R.; Armstrong, K.; Charles, C.Z.; Kawachi, I. Getting Black Men to Undergo Prostate Cancer Screening: The Role of Social Capital. Am. J. Mens Health 2015, 9, 385-396. [CrossRef] [PubMed]

100. Devellis, B.M.; Blalock, S.J.; Sandler, R.S. Predicting Participation in Cancer Screening: The Role of Perceived Behavioral Control. J. Appl. Soc. Psychol. 1990, 20, 639-660. [CrossRef]

101. Dillard, A.J.; Ferrer, R.A.; Ubel, P.A.; Fagerlin, A. Risk Perception Measures' Associations with Behavior Intentions, Affect, and Cognition Following Colon Cancer Screening Messages. Health Psychol. 2012, 31, 106-113. [CrossRef] [PubMed]

102. Ding, Z.; Zhang, J.-H.; Li, X.-H. Investigation and Analysis on Current Situation of Community Residents' Knowledge of Colorectal Cancer. J. China Med Univ. 2013, 42, 1039-1042.

103. Fernandez, M.E.; Diamond, P.M.; Rakowski, W.; Gonzales, A.; Tortolero-Luna, G.; Williams, J.; Morales-Campos, D.Y. Development and Validation of a Cervical Cancer Screening Self-Efficacy Scale for Low-income Mexican American Women. Cancer Epidemiol. Biomark. Prev. 2009, 18, 866-875. [CrossRef]

104. Flynn, P.M.; Betancourt, H.; Ormseth, S.R. Culture, Emotion, and Cancer Screening: An Integrative Framework for Investigating Health Behavior. Ann. Behav. Med. 2011, 42, 79-90. [CrossRef] [PubMed]

105. Gharoro, E.P.; Ikeanyi, E.N. An appraisal of the level of awareness and utilization of the Pap smear as a cervical cancer screening test among female health workers in a tertiary health institution. Int. J. Gynecol. Cancer 2006, 16, 1063-1068. [CrossRef]

106. Hart, S.L.; Bowen, D.J. Sexual Orientation and Intentions to Obtain Breast Cancer Screening. J. Womens Health 2009, 18, 177-185. [CrossRef]

107. Hay, J.L.; Ford, J.S.; Klein, D.; Primavera, L.H.; Buckley, T.R.; Stein, T.R.; Shike, M.; Ostroff, J.S. Adherence to colorectal cancer screening in mammography-adherent older women. J. Behav. Med. 2003, 26, 553-576. [CrossRef]

108. Hay, J.L.; Ramos, M.; Li, Y.; Holland, S.; Brennessel, D.; Kemeny, M.M. Deliberative and intuitive risk perceptions as predictors of colorectal cancer screening over time. J. Behav. Med. 2016, 39, 65-74. [CrossRef]

109. Ivanov, L.L.; Hu, J.; Leak, A. Immigrant Women's Cancer Screening Behaviors. J. Community Health Nurs. 2010, $27,32-45$. [CrossRef]

110. Jacobsen, P.B.; Lamonde, L.A.; Honour, M.; Kash, K.; Hudson, P.B.; Pow-Sang, J. Relation of family history of prostate cancer to perceived vulnerability and screening behavior. Psycho Oncol. 2004, 13, 80-85. [CrossRef]

111. Juon, H.-S.; Guo, J.; Kim, J.; Lee, S. Predictors of Colorectal Cancer Knowledge and Screening Among Asian Americans Aged 50-75 years old. J. Racial Ethn. Health Disparities 2017, 5, 545-552. [CrossRef]

112. Katapodi, M.C.; Dodd, M.J.; Lee, K.A.; Facione, N.C. Underestimation of Breast Cancer Risk: Influence on Screening Behavior. Oncol. Nurs. Forum 2009, 36, 306-314. [CrossRef] [PubMed]

113. Kawar, L.N. Jordanian and Palestinian Immigrant Women's Knowledge, Affect, Cultural Attitudes, Health Habits, and Participation in Breast Cancer Screening. Health Care Women Int. 2009, 30, 768-782. [CrossRef]

114. Kim, B.K.; Jo, H.S.; Lee, H.J. Study on the Factors Related with Intention of Cancer Screening Among Korean Residents: Application of Information-Motivation-Behavioral Skills Model. Asia-Pac. J. Public Health 2015, 27, NP2133-NP2143. [CrossRef] [PubMed]

115. Kowalski, R.M.; Brown, K.J. Psychosocial Barriers to Cervical Cancer Screening: Concerns with Self-presentation and Social Evaluation. J. Appl. Soc. Psychol. 1994, 24, 941-958. [CrossRef]

116. Kudadjie-Gyamfi, E.K.; Magai, C.; Consedine, N.S. The obscuring object of race: Clinical breast exams and coping styles in ethnic subpopulations of women. Br. J. Health Psychol. 2010, 15, 289-305. [CrossRef]

117. Lechner, L.; de Vries, H.; Offermans, N. Participation in a breast cancer screening program: Influence of past behavior and determinants on future screening participation. Prev. Med. 1997, 26, 473-482. [CrossRef]

118. Lee, E.E.; Fogg, L.; Menon, U. Knowledge and Beliefs Related to Cervical Cancer and Screening Among Korean American Women. West. J. Nurs. Res. 2008, 30, 960-974. [CrossRef]

119. Lee, F.-H.; Wang, H.-H.; Yang, Y.-M.; Huang, J.-J.; Tsai, H.-M. Influencing Factors of Intention to Receive Pap Tests in Vietnamese Women who Immigrated to Taiwan for Marriage. Asian Nurs. Res. 2016, 10, 189-194. [CrossRef]

120. Lindberg, N.M.; Wellisch, D. Anxiety and compliance among women at high risk for breast cancer. Ann. Behav. Med. 2001, 23, 298-303. [CrossRef]

121. Lostao, L.; Joiner, T.E.; Pettit, J.W.; Chorot, P.; Sandin, B. Health beliefs and illness attitudes as predictors of breast cancer screening attendance. Eur. J. Public Health 2001, 11, 274-279. [CrossRef] [PubMed]

122. Manne, S.; Markowitz, A.; Winawer, S.; Guillem, J.; Meropol, N.J.; Haller, D.; Jandorf, L.; Rakowski, W.; Babb, J.; Duncan, T. Understanding intention to undergo colonoscopy among intermediate-risk siblings of colorectal cancer patients: A test of a mediational model. Prev. Med. 2003, 36, 71-84. [CrossRef]

123. McGregor, L.M.; von Wagner, C.; Vart, G.; Yuen, W.C.; Raine, R.; Wardle, J.; Robb, K.A. The impact of supplementary narrativebased information on colorectal cancer screening beliefs and intention. BMC Cancer 2015, 15, 162. [CrossRef]

124. McQueen, A.; Vernon, S.W.; Rothman, A.J.; Norman, G.J.; Myers, R.E.; Tilley, B.C. Examining the Role of Perceived Susceptibility on Colorectal Cancer Screening Intention and Behavior. Ann. Behav. Med. 2010, 40, 205-217. [CrossRef] [PubMed] 
125. Miles, A.; Rainbow, S.; von Wagner, C. Cancer Fatalism and Poor Self-Rated Health Mediate the Association between Socioeconomic Status and Uptake of Colorectal Cancer Screening in England. Cancer Epidemiol. Biomark. Prev. 2011, 20, $2132-2140$. [CrossRef] [PubMed]

126. Mirzaei-Alavijeh, M.; Heydari, S.T.; Ahmadi-Jouybari, T.; Jalilian, F.; Gharibnavaz, H.; Mahboubi, M. Socio-Demographic and Cognitive Determinants of Breast Cancer Screening. Int. J. Adv. Biotechnol. Res. 2017, 8, 539-545. [CrossRef]

127. Mitchell, J.A.; Watkins, D.C.; Modlin, C.S., Jr. Social Determinants Associated with Colorectal Cancer Screening in an Urban Community Sample of African-American Men. J. Mens. Health 2013, 10, 14-21. [CrossRef] [PubMed]

128. Muliira, J.K.; Al-Saidi, H.S.; Al-Yahyai, A.N. Determinants of behavioral intentions to screen for prostate cancer in Omani men. Asia-Pac. J. Oncol. Nurs. 2017, 4, 348-355. [CrossRef]

129. Murray, M.; McMillan, C. Health beliefs, locus of control, emotional control and women's cancer screening behaviour. Br. J. Clin. Psychol. 1993, 32 Pt 1, 87-100. [CrossRef]

130. Nguyen, A.B.; Clark, T.T.; Belgrave, F.Z. Gender Roles and Acculturation: Relationships With Cancer Screening Among Vietnamese American Women. Cult. Divers. Ethn. Minority Psychol. 2014, 20, 87-97. [CrossRef] [PubMed]

131. O’Donnell, S.; Goldstein, B.; DiMatteo, M.R.; Fox, S.A.; John, C.R.; Obrzut, J.E. Adherence to Mammography and Colorectal Cancer Screening in Women 50-80 Years of Age: The Role of Psychological Distress. Womens Health Issues 2010, 20, 343-349. [CrossRef]

132. Ogunsanya, M.E.; Brown, C.M.; Odedina, F.T.; Barner, J.C.; Adedipe, T. Determinants of prostate cancer screening intentions of young black men aged 18 to 40 years. J. Racial Ethn. Health Disparities 2017, 4, 1009-1020. [CrossRef]

133. Orbell, S.; Crombie, I.; Johnston, G. Social cognition and social structure in the prediction of cervical screening uptake. Br. J. Health Psychol. 1996, 1, 35-50. [CrossRef]

134. Rahaei, Z.; Ghofranipour, F.; Morowatisharifabad, M.A.; Mohammadi, E. Determinants of cancer early detection behaviors: Application of protection motivation theory. Health Promot. Perspect. 2015, 5, 138. [CrossRef] [PubMed]

135. Rutter, D.R. Attendance and reattendance for breast cancer screening: A prospective 3-year test of the Theory of Planned Behaviour. Br. J. Health Psychol. 2000, 5, 1-13. [CrossRef]

136. Savage, S.A.; Clarke, V.A. Factors associated with screening mammography and breast self-examination intentions. Health Educ. Res. 1996, 11, 409-421. [CrossRef]

137. Sen, C.K.N.; Baruh, L.; Kumkale, G.T. Beyond a Paycheck: The Influence of Workforce Participation on Women's Cancer Screening in Turkey. Sex Roles 2016, 75, 599-611. [CrossRef]

138. Shelton, R.C.; Winkel, G.; Davis, S.N.; Roberts, N.; Valdimarsdottir, H.; Hall, S.J.; Thompson, H.S. Validation of the Group-Based Medical Mistrust Scale Among Urban Black Men. J. Gen. Intern. Med. 2010, 25, 549-555. [CrossRef] [PubMed]

139. Subramanian, P.; Oranye, N.O.; Masri, A.M.; Taib, N.A.; Ahmad, N. Breast Cancer Knowledge and Screening Behaviour among Women with a Positive Family History: A Cross Sectional Study. Asian Pac. J. Cancer Prev. 2013, 14, 6783-6790. [CrossRef]

140. Talley, C.H.; Yang, L.; Williams, K.P. Breast Cancer Screening Paved with Good Intentions: Application of the InformationMotivation-Behavioral Skills Model to Racial/Ethnic Minority Women. J. Immigr. Minority Health 2017, 19, 1362-1371. [CrossRef] [PubMed]

141. Tanjasiri, S.P.; Mouttapa, M.; Sablan-Santos, L.; Quitugua, L.F. What Promotes Cervical Cancer Screening Among Chamorro Women in California? J. Cancer Educ. 2012, 27, 725-730. [CrossRef]

142. Thompson, V.L.S.; Harris, J.; Clark, E.M.; Purnell, J.; Deshpande, A.D. Broadening the examination of sociocultural constructs relevant to African-American colorectal cancer screening. Psychol. Health Med. 2015, 20, 47-58. [CrossRef]

143. VanDyke, S.D.; Shell, M.D. Health Beliefs and Breast Cancer Screening in Rural Appalachia: An Evaluation of the Health Belief Model. J. Rural Health 2017, 33, 350-360. [CrossRef]

144. Yeh, V.M.; Schnur, J.B.; Margolies, L.; Montgomery, G.H. Dense Breast Tissue Notification: Impact on Women's Perceived Risk, Anxiety, and Intentions for Future Breast Cancer Screening. J. Am. Coll. Radiol. 2015, 12, 261-266. [CrossRef]

145. Yu, M.-Y.; Wu, T.-Y.; Mood, D.W. Cultural affiliation and mammography screening of Chinese women in an urban county of Michigan. J. Transcult. Nurs. Off. J. Transcult. Nurs. Soc. 2005, 16, 107-116. [CrossRef] [PubMed]

146. Fishbein, M.; Cappella, J.N. The Role of Theory in Developing Effective Health Communications. J. Commun. 2006, 56, S1-S17. [CrossRef]

147. Webb, T.L.; Sheeran, P. Does changing behavioral intentions engender behavior change? A meta-analysis of the experimental evidence. Psychol. Bull. 2006, 132, 249-268. [CrossRef] [PubMed]

148. Bish, A.; Sutton, S.; Golombok, S. Predicting uptake of a routine cervical smear test: A comparison of the health belief model and the theory of planned behaviour. Psychol. Health 2000, 15, 35-50. [CrossRef]

149. Fishbein, M. The role of theory in HIV prevention. Aids Care 2000, 12, 273-278. [CrossRef]

150. Gollwitzer, P.M. Goal Achievement: The Role of Intentions. Eur. Rev. Soc. Psychol. 1993, 4, 141-185. [CrossRef]

151. Gollwitzer, P.M.; Sheeran, P. Implementation Intentions and Goal Achievement: A Meta-analysis of Effects and Processes. In Advances in Experimental Social Psychology; Academic Press: Cambridge, MA, USA, 2006; Volume 38, pp. 69-119.

152. Bowdy, M.A. The Cues to Behavior Change Model: Integration of the Health Belief Model. and the Transtheoretical Model; University of Kentucky: Lexington, KY, USA, 1998.

153. Champion, V.; Maraj, M.; Hui, S.; Perkins, A.J.; Tierney, W.; Menon, U.; Skinner, C.S. Comparison of tailored interventions to increase mammography screening in nonadherent older women. Prev. Med. 2003, 36, 150-158. [CrossRef] 
154. Manne, S.; Markowitz, A.; Winawer, S.; Meropol, N.J.; Haller, D.; Rakowski, W.; Babb, J.; Jandorf, L. Correlates of colorectal cancer screening compliance and stage of adoption among siblings of individuals with early onset colorectal cancer. Health Psychol. 2002, 21, 3-15. [CrossRef]

155. Sniehotta, F.F.; Scholz, U.; Schwarzer, R. Bridging the intention-behaviour gap: Planning, self-efficacy, and action control in the adoption and maintenance of physical exercise. Psychol. Health 2005, 20, 143-160. [CrossRef]

156. Schwarzer, R. Modeling Health Behavior Change: How to Predict and Modify the Adoption and Maintenance of Health Behaviors. Appl. Psychol. 2008, 57, 1-29. [CrossRef]

157. Donohue, G.A.; Tichenor, P.J.; Olien, C.N. Mass Media and the Knowledge Gap: A Hypothesis Reconsidered. Commun. Res. 1975, 2, 3-23. [CrossRef]

158. Scarinci, I.C.; Beech, B.M.; Kovach, K.W.; Bailey, T.L. An Examination of Sociocultural Factors Associated with Cervical Cancer Screening Among Low-Income Latina Immigrants of Reproductive Age. J. Immigr. Health 2003, 5, 119-128. [CrossRef] [PubMed]

159. Weller, D.P.; Campbell, C. Uptake in cancer screening programmes: A priority in cancer control. Br. J. Cancer 2009, 101, S55-S59. [CrossRef]

160. Eisend, M. Meta-Analysis in Advertising Research. J. Advert. 2017, 46, 21-35. [CrossRef]

161. James, M.G. Measuring love in romantic relationships: A meta-analysis. J. Soc. Pers. Relatsh. 2010, 28, 748-771. [CrossRef]

162. Milhabet, I.; Duprez, C.; Krzeminski, A.; Christophe, V. Cancer risk comparative perception and overscreening behaviours of non-carriers from BRCA1/2 families. Eur. J. Cancer Care 2013, 22, 540-548. [CrossRef] [PubMed] 